\title{
Molecular Major Response
}

National Cancer Institute

\section{Source}

National Cancer Institute. Molecular Major Response. NCI Thesaurus. Code C123594.

A decrease in signs of cancer, supported by molecular analysis. 